\title{
Diferentes tendências em pesquisas sobre a fala egocêntrica: análise de produções brasileiras
}

Different tendencies in research on egocentric speech: analysis of Brazilian productions

\author{
Alessandra de Morais \\ Universidade Estadual Paulista (UNESP), Marília, São Paulo, Brasil. \\ alemorais.shimizu@gmail.com \\ Bruna Assem Sasso \\ Universidade Estadual Paulista (UNESP), Marília, São Paulo, Brasil. \\ bru.sasso@hotmail.com
}

Resumo: O objetivo desta investigação foi o de realizar uma revisão de pesquisas desenvolvidas no Brasil sobre a fala egocêntrica, de forma a identificar as principais questões teórico-metodológicas presentes em seu estudo. A busca foi feita no banco de Teses da CAPES e abarcou o período de 1987 a 2012; foram encontradas oito teses / dissertações. Os resultados demonstraram a abordagem predominante da fala egocêntrica à luz da perspectiva Histórico-Cultural, de Vigotski, com a presença, sobretudo, de duas tendências: estudos que confirmam seus postulados e os que sugerem contribuições de outros teóricos, em especial de Bakhtin. Uma terceira tendência foi também reconhecida, que, embora sinalize para os trabalhos de Piaget e Vigotski, tece críticas a ambos e não adere a nenhum deles.

Palavras-chave: desenvolvimento da Linguagem; fala egocentric; implicações educacionais.

Abstract: The purpose of this research was to conduct a review of research developed in Brazil about egocentric speech, in order to identify key theoretical and methodological issues present in its study. A search was made in the CAPES Thesis databank, comprising the period from 1987 to 2012, and eight 
theses / dissertations were found. The results demonstrated the predominance of studies in the light of Vygotsky's cultural-historical perspective, which can be divided according to two tendencies: those studies that confirm its postulates and those that suggest other theoretical contributions, particularly from the Circle of Bakhtin. A third tendency can also be recognized which, although signaling to the work of Piaget and Vigotski, criticizes both and does not adhere to any of them, proposing a different way of conceiving this linguistic occurrence.

Keywords: language development; egocentric speech; educational implications.

Recebido em: 9 de outubro de 2014. Aprovado em: 15 de abril de 2015.

\section{Introdução}

Tem-se como foco a fala egocêntrica, no intuito de se compreender sua abordagem em produções brasileiras, uma vez que, desde que foi considerada objeto de estudo, não ficou imune a controvérsias decorrentes das diferentes acepções a ela concernentes. Este trabalho não se detém em reconhecer qual teoria seria mais plausível para explicar esse tipo de linguagem, porém, volta-se para as respectivas formulações realizadas no âmbito da Epistemologia e Psicologia Genéticas de Piaget e da Teoria Histórico-Cultural de Vigotski, e, mormente, para as produções que integram o cenário acadêmico brasileiro.

Inicialmente, a fala egocêntrica foi nomeada e conceituada por Piaget, na obra A Linguagem e o Pensamento na Criança (PIAGET, 1923 [1999]), sendo, em seguida, reconhecida por Vigotski (1934 [2001]), em sua importância, no entanto, com discordâncias em relação às interpretações de Piaget. Todavia, foi somente após 25 anos que Piaget teve acesso às considerações de Vigotski, o que lamentou, expressando seu forte desejo por um encontro pessoal em que pudessem ter discutido diversos pontos relevantes. Mesmo impossibilitado de satisfazer a essa sua aspiração, Piaget (1966) se voltou às observações de 
Vigotski, procurando respondê-las e analisá-las à luz de seus trabalhos mais atuais.

Com efeito, dando continuidade aos estudos de Piaget e / ou Vigotski, várias investigações foram desenvolvidas, buscando-se entender a gênese, as funções, a estrutura e as implicações da fala egocêntrica. Nessa perspectiva, o objetivo deste estudo é realizar uma revisão das pesquisas realizadas, no Brasil, sobre a fala egocêntrica. Tem-se o intuito de apresentar uma análise crítica e sistematizada do conhecimento acumulado sobre essa temática, possibilitando sua contextualização, problematização e identificação das principais questões teórico-metodológicas presentes, de modo a analisar as aproximações, distanciamentos e / ou ampliações sobre as duas abordagens que inauguraram esse campo de investigação - a Epistemologia e Psicologia Genéticas, de Piaget, e a Teoria Histórico-Cultural, de Vigotski.

Diante do exposto, antes de iniciar a apresentação da pesquisa bibliográfica efetuada, considera-se pertinente explanar, brevemente e de forma introdutória, sobre alguns aspectos: a fala egocêntrica em Piaget, a crítica de Vigotski a Piaget, a fala egocêntrica em Vigotski e as respostas de Piaget a Vigotski.

\section{A fala egocêntrica em Piaget e Vigotski}

Piaget (1923[1999]) divide a linguagem da criança em dois grandes grupos - socializado e egocêntrico - que se diferenciam basicamente por suas funções. De maneira geral, no primeiro, a criança tenta estabelecer comunicação com outras, informando, trocando ideias, pedindo, ordenando, ameaçando, criticando, perguntando. Já no segundo, a criança não se preocupa em saber a quem fala nem se é escutada; "[...] esta linguagem é egocêntrica, em primeiro lugar, porque a criança não fala a não ser de si mesma, e, em segundo lugar, porque não procura colocar-se no ponto de vista do interlocutor" (PIAGET, 1923[1999], p. 8). Para Piaget (1923 [1999]), a fala egocêntrica se reparte em três categorias: a repetição (ecolalia), o monólogo, e o monólogo a dois ou coletivo. Genericamente, por ecolalia se entenderia apenas a repetição de sílabas ou de palavras pelo prazer de falar, sem nenhuma preocupação de 
se dirigir a alguém, nem mesmo, porventura, de pronunciar palavras que tenham sentido. Nas outras duas formas de fala egocêntrica, a criança fala para si mesma, como se pensasse em voz alta, não se dirigindo a ninguém (monólogo); ou fala sem conseguir fazer-se escutar pelos interlocutores, porque não se volta realmente a eles, visto que, na verdade, não se dirige a ninguém - tanto faz que o interlocutor compreenda ou não, mas se supõe escutada e isso é tudo o que deseja-, ou apenas fala alto para si mesma diante dos outros (monólogo a dois ou coletivo).

Em ambos - tanto no monólogo quanto no monólogo a dois ou coletivo -, "[...] se a criança permanece inteiramente restrita a seu ponto de vista, é por acreditar que todas as pessoas pensam como ela" (PIAGET, 1947[2005], p. 141); assim, tanto seu sentimento de resistência das coisas é tão inexistente quanto o da dificuldade das demonstrações; por isso, também, afirma sem provas, dado que não sente a necessidade de convencer, pois, em sua concepção, não há multiplicidade de perspectivas (sua perspectiva é a única possível) (PIAGET, 1924[1967]). Desse modo, a linguagem, ao se relacionar à forma com que a criança compreende os fenômenos do mundo, se apresentará como, ao mesmo tempo, uma manifestação de seu egocentrismo - pela dificuldade de descentração e conseguinte impossibilidade de coordenação das perspectivas.

No texto A linguagem e o pensamento da criança na teoria de Piaget, Vigotski (1934[2001]) desenvolve e apura toda uma argumentação, de sorte a criticar a interpretação de Piaget sobre a questão do egocentrismo e da fala egocêntrica. Suas críticas se concentram, especialmente, no fato de Piaget fazer referência a um tipo de pensamento infantil - o egocentrismo - como caracteristicamente intermediário e transitório entre formas primárias e superiores de pensamento, além de Piaget não ter relevado suficientemente o aspecto funcional da fala egocêntrica. De acordo com Vigotski (1934[2001]), isso se deve à circunstância de a fala egocêntrica se apresentar, nas descrições de Piaget, como produto secundário da atividade infantil, como descoberta do caráter egocêntrico do seu pensamento; assim, segundo Vigotski (1934[2001], p. 51), para Piaget, "[...] a linguagem egocêntrica não desempenha nenhuma função objetivamente útil no 
comportamento da criança. É uma linguagem para si, para a própria satisfação, que poderia nem existir que nada de essencial mudaria na atividade infantil". Outrossim, contesta Piaget quanto ao destino que este dá à fala egocêntrica, porque Vigotski (1934[2001]) defende que, na medida em que se socializa, deveria ser cada vez mais explicitada e compreensível aos outros. Na opinião de Piaget, no entanto, não é isso que ocorre - a fala egocêntrica simplesmente se extinguiria e congelaria, desaparecendo no limiar da idade escolar.

Para Vigotski (1934[2001]), nem a função nem o destino da linguagem egocêntrica confirmam a já referida tese de Piaget, segundo a qual a fala egocêntrica da criança é expressão direta do seu pensamento egocêntrico. Além do mais, Vigotski (1934[2001]) sustenta que a fala egocêntrica da criança não só pode não ser expressão do pensamento egocêntrico, como ainda exerce uma função diametralmente oposta ao pensamento egocêntrico, a saber, a função do pensamento realista.

Mediante diversas investigações, Vigotski (1934[2001]) conclui que a função dessa linguagem é expressiva, de descarga, de formar o plano de solução de uma tarefa que surge no comportamento. Assim, sua função compreende o planejamento e a direção da futura ação; ele alega que, quando há a complicação da tarefa, o uso da linguagem emocional aumenta, assim como os esforços da criança para atingir uma solução mais inteligente e menos automática. Nessa mesma linha, Vigotski (2007) vai aduzir que a fala egocêntrica está ligada à social por meio de várias formas de transição.

O primeiro exemplo dessa ligação é que, quando não consegue resolver um problema por si, as crianças recorrem ao adulto e descrevem o método o qual não conseguiram colocar em ação. A outra e maior mudança na capacidade da criança de fazer uso da linguagem como um instrumento de solução de problemas acontece quando, no seu desenvolvimento, há a internalização da fala socializada e, em vez de solicitar a ajuda a um adulto, a criança recorre a si mesma. Nesse momento, ela coloca a si mesma uma atitude social, uma vez que desenvolve um método de comportamento para guiar-se, o qual tinha sido utilizado anteriormente em relação a outra pessoa, organizando sua atividade com base em uma forma social de comportamento. 
Isso porque, Vigotski (1934[2001]) postula que, em seu desenvolvimento filogenético e ontogenético, o pensamento e a fala têm raízes genéticas diferentes, desenvolvendo-se em trajetórias independentes e distintas, uma vez que o pensamento encontra-se em uma fase pré-linguística - por justamente manifestar-se por meio de uma inteligência prática e de forma independente "das reações intelectuais rudimentares em relação à fala" (p. 129) -, e a fala detém-se ao comportamento predominantemente emocional e de contato social, isto é, pré-racional. Mas, em certo momento, por volta dos dois anos de idade, as curvas da evolução do pensamento e da fala, até então separadas, encontram-se - por causa da inserção da criança no convívio e interação em grupos sociais e membros mais maduros da cultura-, unindo-se para iniciar uma nova forma de comportamento, em que "o pensamento se torna verbal e a fala se torna intelectual" (p. 131). A linguagem passa, então, a ter função simbólica e generalizante e o pensamento a ser mediado pelos significados da linguagem.

Vigotski indica, portanto, que a linguagem egocêntrica da criança deve ser vista como uma forma de transição entre a fala exterior e a interior: "Funcionalmente, a fala egocêntrica é a base para a fala interior, enquanto em sua forma externa está incluída na fala comunicativa." (VIGOTSKI, 2007, p. 15). Nesse contexto, a linguagem egocêntrica, para Vigotski (1934[2001], p.136) "[...] se torna pensamento na verdadeira acepção do termo". A linguagem interior terá seu desenvolvimento por meio de mudanças estruturais e funcionais, separando-se da linguagem exterior, ocorrendo sua diferenciação no que tange às funções sociais e egocêntricas da linguagem, até que as estruturas da linguagem dominadas pela criança se transformarão em estruturas básicas de seu pensamento.

Ainda segundo Vigotski (2007), a relação entre a fala e a ação sofre mudanças no desenvolvimento da criança e na função da fala sobre ela. Em um primeiro momento, a fala acompanha a ação, os problemas são solucionados de maneira caótica e dispersa, quando a fala é provocada e acompanhada pela atividade. Posteriormente, a fala antecede a ação, de modo a dirigir, determinar e dominar seu curso, tendo assim uma função planejadora e de refletir o mundo exterior. 
Quanto ao destino da fala egocêntrica, a conjetura de Vigotski (1934[2001]) é a de que o rápido declínio de seu coeficiente na idade escolar se deve aos processos de linguagem interior que se constituem na criança, mais ou menos na primeira idade escolar. Dessa forma, para o autor, a via que conduz ao surgimento da fala egocêntrica é diametralmente oposta àquela traçada nas investigações de Piaget, já que a hipótese de Vigotski (1934 [2001]) é a de que "[...] a linguagem egocêntrica surge com base na linguagem social, com a criança transferindo formas sociais de pensamento e formas de colaboração coletiva para o campo das funções psicológicas pessoais.” (p. 64). Nesse sentido, para Vigotski, o movimento real do processo de desenvolvimento do pensamento infantil se realiza do social para o individual.

Posteriormente, Piaget (1966) lamentou que a obra de Vigotski só viesse a seu conhecimento após a morte daquele estudioso, impossibilitando-os de discutirem pessoalmente e detalhadamente muitos pontos de interesse mútuo. Procurou, então, ponderar se as críticas de Vigotski eram ou não justificadas, à luz de seus mais recentes trabalhos e a resposta foi, ao mesmo tempo, sim e não. De forma sintética, pode-se considerar que, sobre a relação entre pensamento egocêntrico e fala egocêntrica, Piaget reconhece que ambos são fenômenos distintos e que o egocentrismo intelectual vai além do social. Em decorrência disso, defende a existência do egocentrismo intelectual, sendo que o referido pensamento egocêntrico não se reduz à linguagem egocêntrica, a qual, por sua vez, relaciona-se também com o egocentrismo social; por isso mesmo, não pode ser desconsiderado como um fenômeno importante para se reconhecer a lógica da criança.

O próprio Piaget (1966), além de argumentar que não há como não reconhecer o egocentrismo intelectual, no campo das relações interpessoais, e, tendo em vista sua expressão na linguagem, admite igualmente que haja grande variação na mensuração da linguagem egocêntrica, conforme os ambientes e as situações. Por seu turno, ao desconsiderar o pensamento egocêntrico na criança, Vigotski não reconhece esse fenômeno e suas repercussões no desenvolvimento psicológico. 
Desse modo, ao ponderar que cada troca entre a criança e o seu ambiente pode ser sujeita a limitações, as quais não garantem o êxito, desde o início, Piaget (1966) critica Vigotski por seu otimismo quanto aos processos adaptativos, ao não considerar a relação entre o egocentrismo intelectual e o erro sistemático - decorrente do fenômeno do egocentrismo-, que constitui, na criança, um dos maiores obstáculos à coordenação de perspectivas, descentração e cooperação. Piaget (1966) admitira ainda que é razoável pensar na transformação da fala egocêntrica em fala interna e, embora concorde com Vigotski sobre que a função inicial da linguagem deve ser a de comunicação, diferenciando a fala egocêntrica e a comunicativa propriamente dita, exprime aversão a seu posicionamento, quanto à consideração de que essas duas formas linguísticas possam ser igualmente socializadas (ou com função de socialização). Isso justifica o motivo pelo qual Piaget (1966) se referiu com certa indignação a Vigotski, por ele ter dado mais relevo à questão da fala egocêntrica e não ter levado em conta o fenômeno do egocentrismo como principal obstáculo à coordenação dos pontos de vista e à cooperação, pois, segundo Piaget (PIAGET, 1923[1999]), o egocentrismo verbal é apenas um indício, e não a causa primeira, convindo determinar as relações precisas desse indício com as realidades mais profundas que ele manifesta, antes de valer-se das variações para contestar sua significação.

$\mathrm{Na}$ sequência das formulações e discussões de Piaget (1923[1999], 1966) e Vigotski (1934[2001], 2007) - dois dos estudiosos mais representativos da área da Psicologia Genética - sobre a fala egocêntrica, podem ser encontrados vários estudos que se voltam para essa temática, os quais têm sido desenvolvidos por teóricos de diferentes áreas - sobretudo na área da Aquisição da Linguagem - e países (WEIR, 1962; FLAVELL, 1966; DIAZ, 1992; RAMIREZ, 1992; MONTERO; DIOS; HUERTAS, 2001; WINSLER; NAGLIERI, 2003; SAN MARTÍN, 2004, 2008; MONTERO; DIOS, 2006; BERK, 2007, entre outros).

Acerca desses autores que vêm tratando mundialmente a fala egocêntrica, na sua obra, Ruth Weir (1962) cunhou o termo "language practice", o qual vingou na área de Aquisição de Linguagem - área em que, com exceção de seu trabalho de 1962, é bastante recente o interesse 
pela fala egocêntrica. Seu objetivo primeiro é oferecer, com base nos monólogos no berço, argumentos favoráveis à ideia de que as "produções solitárias" da criança exibem sua independência em relação ao outro, independência que é correlativa ao controle gradual que passa a ter dos padrões da língua; e sua tese se aproxima, dessa forma, de Vigotski, ao assumir a noção de internalização implicando-lhe uma subjetividade que se desenvolve e se consolida em uma esfera privada, em um retiro interno / individual. Flavell (1966), por sua vez, em seu artigo "Le langage privé", apresenta o vocábulo "fala privada" com o propósito de distinguir, com clareza, o fenômeno geral da linguagem de fala para si próprio, da interpretação piagetiana sobre esse fato.

Diaz (1992) fornece uma análise em profundidade das questões metodológicas críticas no estudo da fala privada, e aborda quatro questões metodológicas, oferecendo sugestões concretas para resolvê-las que prometem aumentar a sofisticação de pesquisas futuras. San Martín (2004, 2008), além de ter investigado a função planejadora e lúdico emocional da fala privada, aponta que não apenas a dificuldade na tarefa conduz à emergência desta fala, mas situações de conflito comunicativo (ou seja, expressão e confrontação de perspectivas diferentes) as provocaram no grupo estudado. Ao também discutir estudos realizados com crianças e a emergência de fala privada de caráter afetivo e de fantasia, concorda com Berk e Diaz (1992) que, possivelmente, os contextos lúdicos podem emergir como contextos privilegiados para a exploração dessas outras possíveis funções.

Outrossim, Berk (2007) apresenta dados de sua pesquisa na qual ela acompanhou 16 "indiozinhos" apaches de faixa etária entre 5 a 10 anos, e notou que a linguagem egocêntrica, do ponto de vista de Piaget, raramente ocorria, pois falavam mais consigo mesmas quando executavam sozinhas tarefas desafiadoras ou quando seus professores não podiam ajudá-las de imediato. Para a autora, a linguagem egocêntrica, além de ser um instrumento de resolução de problemas, universalmente disponível para aqueles que crescem em ambientes ricos em interações sociais, trata-se de um comportamento saudável e adaptativo.

Ademais, outros autores (bem como supracitado, por exemplo: WINSLER; NAGLIERI, 2003; MONTERO; DIOS; HUERTAS, 2001; 
MONTERO; DIOS, 2006; RAMÍREZ,1992), tiveram fala privada como alvo de suas investigações. Os primeiros se interessaram, sobretudo, pela transição das crianças para a escola, no desenvolvimento da autorregulação, na fala privada, na teoria sociocultural de Vigotski, no bilinguismo e na escolaridade precoce de alunos da língua inglesa. Já Montero, Dios e Huertas (2001) propuseram-se a explorar o papel da fala privada como ferramenta de motivação, indo além da pesquisa clássica na sua função reguladora para processos cognitivos como atenção ou função executiva; e os dados das pesquisas de Montero e Dios (2006) sugerem que é possível apoiar mais fortemente a função motivacional da fala privada, fornecendo dados relevantes para que se estenda a função de autorregulação de expressão para além da atividade motora e certas habilidades cognitivas, sem contradizer a teoria de Vigotski sobre a natureza mediada das funções psicológicas superiores. De semelhante modo, Ramirez (1992) sugere que o diálogo mental, entre Eu-falante e Eu-ouvinte, manifesta-se como fala privada. Sendo que esse ponto de vista do desenvolvimento do $e u$, por meio das perspectivas dos outros, requer à criança adotar papéis diferentes em contextos sociais e, portanto, faz uma afirmação implícita sobre a compreensão das crianças de perspectivas mentais distintas na mesma situação.

Destarte, procurando atender aos objetivos desta pesquisa, a seguir serão apresentados e analisados aqueles estudos produzidos nos programas brasileiros de Pós-Graduação, nas últimas três décadas, procurando-se compreender quais suas principais características e contribuições.

\section{Procedimentos Metodológicos}

A investigação realizada foi de abordagem qualitativa e de natureza bibliográfica. Consistiu no levantamento e análise de teses e dissertações defendidas nos Programas brasileiros de Pós-Graduação, reconhecidos pela CAPES - Coordenação de Aperfeiçoamento de Pessoal de Nível Superior-, que abordassem a fala egocêntrica. O levantamento foi feito no Banco de Teses da CAPES, que disponibiliza os resumos de teses e dissertações defendidas desde 1987. A busca foi 
executada no início de 2013 e abarcou todos os anos de base (de 1987 a 2012). Os descritores utilizados foram "fala egocêntrica", "linguagem egocêntrica" e "fala privada".

Procurou-se contemplar, na análise do material, os seguintes aspectos: a área de inserção da tese / dissertação; o referencial teórico no qual o trabalho se fundamenta; os objetivos do estudo; o tipo de pesquisa realizada; os sujeitos participantes e o contexto priorizado; os resultados alcançados, e as implicações educacionais decorrentes.

Antes de iniciar a exposição dos dados obtidos, esclarecimentos sobre a terminologia empregada se fazem necessários. Por fidelidade aos trabalhos pesquisados, foram mantidos os termos usados por seus respectivos autores. Assim, na apresentação dos textos, algumas vezes foi utilizado o termo fala egocêntrica, outras, linguagem egocêntrica, monólogos ou ainda fala privada.

\subsection{Resultados do Levantamento Bibliográfico}

Por meio da pesquisa efetivada, foram encontrados oito produtos (cinco dissertações de Mestrado e três teses de Doutorado), os quais foram adquiridos na íntegra e analisados. Das oito teses / dissertações, três foram desenvolvidas em Programas de Pós-Graduação em Educação (AZULAY, 1995; AGUIAR, 1998; QUAST, 2009); duas em Programas de Psicologia (ANDRADA, 2006; CAVATON, 2010), e três da Linguística (LIER DE VITTO, 1994; FERREIRA, 2000; PINHO, 2009).

Em relação ao referencial no qual as teses / dissertações se fundamentam, constata-se que nenhuma se embasa na Epistemologia e Psicologia Genéticas de Piaget. E, entre aquelas que mencionam essa teoria, fazem-no, sobretudo, no intuito de reiterar as críticas de Vigotski (1934 [2001]) às formulações de Piaget (1923 [1999]), apesar de reconhecerem a importância desse autor na identificação, investigação e descrição da fala egocêntrica. Averigua-se, assim, no conjunto analisado, a predominância da perspectiva Histórico-cultural, com exceção apenas de Lier-De Vitto (1994), a qual, a despeito de sinalizar para os trabalhos de Piaget (1923 [1999]) e Vigotski (1934 [2001]), por terem sido os pioneiros a colocarem em evidência os monólogos da criança sob a 
expressão "fala egocêntrica", tece críticas a ambos e não adere a nenhum eles.

Não obstante os trabalhos, mormente, fundamentarem-se na Teoria Histórico-Cultural, pode ser sugerida a presença de duas tendências: aqueles estudos que confirmam os postulados de Vigotski (1934 [2001], 2007) sobre a linguagem egocêntrica e os que, embora reconheçam a importância de suas formulações e as tenham como referencial de base, apontam para limitações e sugerem que a compreensão desse tipo de linguagem pode ser enriquecida com contribuições provenientes de outros teóricos, em especial, de Bakhtin (1929 [1981], 1929 [1986], 1979 [1992]). Na primeira tendência, inserem-se os estudos de Azulay (1995), Aguiar (1998), Andrada (2006) e Cavaton (2010). Na segunda, os de Ferreira (2000), Pinho (2009) e Quast (2009).

Ademais, haveria, por assim dizer, uma terceira tendência em que se tem uma interpretação alternativa sobre a fala egocêntrica, não sendo admitida nem com base na perspectiva Histórico-cultural, nem na Epistemologia e Psicologia Genéticas. Nesta, encontra-se a pesquisa de Lier-De Vitto (1994). Por conseguinte, devido ao enfoque dado ao momento genético, à estrutura e função da linguagem egocêntrica, os estudos também podem ser diferenciados com base na faixa etária dos sujeitos pesquisados, em que, na primeira tendência, as pesquisas são realizadas com crianças em idade pré-escolar; na segunda, com jovens adultos aprendizes de língua estrangeira, e, na terceira, na qual, ao se voltar para os monólogos no berço, o olhar se dirige para a criança na tenra infância.

No que concerne à presença das obras de Piaget, Vigotski e Bakhtin, nesses estudos, há alguns aspectos dignos de nota. Por exemplo, em relação às de Vigotski, entre as diversas citadas, aquelas que mais comparecem são: Pensamento e linguagem (1934 [1987]), utilizada em todos os estudos das três tendências, e A formação social da mente (1984), referenciada entre os da primeira tendência por Azulay (1995), Andrada (2006) e Cavaton (2010); nos da segunda, por Ferreira (2000) e Quast (2009); e, no da terceira, por Lier-De Vitto (1994). Quanto a Piaget, a obra mais presente é A linguagem e o pensamento na criança (1923 [1986]), citada por todas as autoras da segunda tendência e, na 
primeira, por Azulay (1995) e Cavaton (2010), sendo que as demais autoras dessa tendência não se reportam diretamente a nenhuma obra de Piaget. O texto Comentários de Piaget sobre observações críticas de Vygotsky (1966) é mencionado apenas por uma autora da primeira e uma da segunda tendência, respectivamente Azulay (1995) e Quast (2009). Por sua vez, Lier-De Vitto (1994), representante da terceira tendência, realiza uma leitura de várias obras de Piaget, a saber: A linguagem e $o$ pensamento na criança (1923 [1986]), Comentários de Piaget sobre observações críticas de Vygotsky (1966), A formação do símbolo na criança (1945 [1975]), A linguagem e as operações intelectuais (1973a) e Estudos Sociológicos (1965 [1973b]). Quanto aos escritos de Bakhtin, o mais empregado é Marxismo e filosofia da linguagem (1929 [1986]), referenciado na primeira tendência por Azulay (1995) e Cavaton (2010), e, na segunda, por Ferreira (2000) e Quast (2009). Outras obras de Bakhtin também são lembradas: Problemas da poética de Dostoievski (1929 [1981]), por Cavaton (2010), na primeira tendência, e por Ferreira (2000) e Quast (2009) na segunda; e Estética da criação verbal (1979 [1992]), por Andrada (2006), na primeira tendência, por Ferreira (2000) e Quast (2009) na segunda, e por Lier-De Vitto (1994), na terceira.

Serão focalizados, de início, os trabalhos da primeira tendência. E, sucessivamente, os da segunda e o da terceira.

\subsection{Pesquisas nacionais sobre a fala egocêntrica: primeira tendência}

Como já mencionado, os trabalhos ora denominados como da primeira tendência são aqueles que abordam a fala egocêntrica, sobretudo com base nas formulações de Vigotski e desenvolvem suas pesquisas com crianças em idade pré-escolar. A seguir, são explicitados esses estudos, levando-se em conta os critérios de análise adotados.

Com o objetivo de descobrir, de um lado, que representações sígnicas a criança surda profunda congênita utiliza para dar significado ao seu pensamento em desenvolvimento e, de outro, se existe "fala" egocêntrica nesta criança e como se expressam suas manifestações, Azulay (1995) realiza, além de um estudo de caráter qualitativo (descritivo), referente a questões que envolvem a abordagem do desenvolvimento cognitivo e das raízes histórico-sociais da linguagem, 
também uma investigação de caráter comparativo. Assim, cotejou uma população-alvo de crianças surdas (oito crianças surdas profundas congênitas, com idade entre dois e cinco anos, sem nenhuma língua adquirida, seja portuguesa, seja de sinais), com uma população de crianças ouvintes (no caso, quatro crianças, com idade entre dois a quatro anos). Embora seu objetivo não se detivesse em provar ou comparar os pressupostos de Piaget e Vigotski relacionados à quantidade de linguagem egocêntrica na criança surda, esses referenciais são expostos por Azulay (1995); porém, nas considerações dos resultados encontrados e nas sugestões de aplicações pedagógicas, indicadas ao término do trabalho, percebe-se a influência epistemológica da teoria vigotskiana.

A investigação ocorreu no Instituto Nacional de Educação de Surdos (INES). Cada criança participou de duas sessões lúdicas e, por intermédio do registro por vídeos, Azulay (1995) pôde fazer uma classificação dos indicadores considerados como manifestações de linguagem egocêntrica. A autora constatou que tanto as crianças ouvintes como as crianças surdas adotam outras manifestações de linguagem egocêntrica para expressar seu pensamento, entre elas a corporal, uma vez que o corpo também falaria consigo próprio, externalizando, por meio de determinados movimentos analisados, a presença de atividade mental. Exemplos desse tipo de expressão apresentados por Azulay (1995, p. 82-3) são: abrir os braços, balançar os joelhos e bater os pés, como indícios de satisfação; gestos com as mãos, mãos na cabeça, arrastar o pé, diante de frustação e / ou dificuldades; levantar o dedo indicador, balançar a perna e o joelho, em momentos de decisão, entre outros.

Nesse sentido, o corpo não manifestaria apenas ação e emoção mas ainda a reflexão e, de uma forma muito peculiar, que é a exteriorização dela. Entre suas considerações, tem-se que não se deve interromper a criança quando está em atividade lúdica, falando ou gesticulando com o brinquedo ou consigo mesma, pois isso revela momento de atividade pensante, geradora de processo decisório, elemento constituinte e indispensável ao desenvolvimento cognitivo; o fato de a criança estar em atividade concentrada, consigo mesma, falando ou gesticulando, não expressa falta de atividade social, mas exatamente uma introspecção derivante da atividade social, um percurso 
a caminho da interiorização, da atividade intrassubjetiva, de acordo com a teoria de Vigotski.

A fim de abordar a apropriação da linguagem oral / escrita e o seu papel no desenvolvimento humano, de sorte a compreender a importância da ação educativa nesse processo, Aguiar (1998), por uma pesquisa bibliográfica, desenvolve uma detalhada apresentação das concepções de Vigotski sobre a linguagem egocêntrica e suas argumentações contrárias em relação ao posicionamento de Piaget. Conforme Aguiar (1993), a linguagem egocêntrica permite, de acordo com a perspectiva de Vigotski, confirmar uma de suas categorias-chave: a da passagem do interpsíquico para o intrapsíquico, porque seu surgimento anuncia a trajetória dos processos socializados para os internos, um procedimento de transição apresentado na forma externa com características estruturais internas. A autora chama a atenção, igualmente, para o fato de que foi se utilizando de experimentos sobre a fala egocêntrica que o estudioso teorizou sobre a linguagem interna, devido às suas semelhanças funcionais, estruturais e genéticas, sendo mediante aquela que esta se faz acessível à observação.

Com o propósito de entender as dinâmicas interativas em contexto de sala de aula, Andrada (2006), em seu estudo, descreve e analisa como ocorre a construção do conhecimento na interação professora(s)-criança(s), em situação de roda, indicando os tipos de estratégias comunicativas e conhecimentos construídos nesse processo. A pesquisa contou com a participação de sete crianças de ambos os gêneros, com idade entre 24 e 32 meses, e de duas professoras, todas integrantes de uma turma da Educação Infantil. Foram feitas sessões de filmagem, com anotações em diário de campo, ao longo de sete meses, relativas a duas atividades da rotina (de roda inicial e primeira atividade), analisando-se dez episódios com base no método microgenético, com a utilização da conversação adaptada à Psicologia.

Os resultados alcançados por Andrada (2006) demonstraram, no que concerne à fala egocêntrica, que ela compareceu ora com um caráter de fala descritiva, com a função de auxiliar e acompanhar as atividades da criança, ora com a qualidade de planejamento, em que a ação é antecipada pela fala, contribuindo com a organização do pensamento e desenvolvimento da atividade. De acordo com a autora, isso confirma a 
concepção de Vigotski de que, primeiramente, a criança age e fala ao mesmo tempo, atribuindo-se, nesse caso, um caráter descritivo à fala egocêntrica. Gradualmente, a ação passa a ser antecipada pela fala, o que define a função planejadora da fala egocêntrica, até que esta tenha sua diminuição e transformação em uma forma silenciosa, representada pela linguagem interior, a qual ampliará seu papel de instrumento na resolução de problemas.

O trabalho de Cavaton (2010) teve como escopo analisar a fala, o desenho e a escrita de crianças, como ferramentas culturais mediadoras para a construção de conhecimento, nos diferentes tipos de interações, quer no contexto da sala de aula, quer em atividades individuais. A autora considera a fala egocêntrica com base na perspectiva de Vigotski, que atribui a esse fenômeno a função de autorregulação da criança e de regulação das ações, e apresenta estudos contemporâneos que confirmam essas funções, na execução de atividades escolares e do dia a dia.

Essas pesquisas indicam que, ao se depararem com dificuldades no desenvolvimento de tarefas, as crianças empregam uma fala com um caráter de autorregulação, de modo a assumir, paulatinamente, o controle que era desempenhado pelo adulto no desenrolar da atividade, o que atua, assim, como uma Zona de Desenvolvimento Proximal. A investigação de Cavaton (2010) foi feita em uma sala do primeiro ano do Bloco Inicial de Alfabetização de uma escola pública, ao longo de oito meses. Foram observadas e gravadas situações de fala, desenho e escrita de cinco crianças, com idades entre seis e sete anos, em sala de aula, nas interações professora / crianças, criança / criança e criança consigo mesma, além de atividades individuais de cada criança com a pesquisadora.

Os resultados apresentados por Cavaton (2010) demonstraram que a fala egocêntrica apresentou a qualidade de função organizadora do desenho e de soletração da escrita livre. Nas atividades de desenho, a criança falava para si mesma, com a função de organizar seu desenho, anunciar o que ia desenhar e fazer a narrativa da história, ao desenhar. No que tange à escrita, a criança soletrava a relação fonema / grafema, com o propósito de descobrir a letra que deveria usar na palavra ou texto que estava escrevendo. 
Um ponto de destaque nessa pesquisa é que, de acordo com a autora, diferentemente do que estudos apontam, de que a fala egocêntrica tem sua maior frequência no enfrentamento de dificuldades, durante a realização de tarefas, os resultados evidenciaram que, quando a criança tenta escrever ou copiar uma palavra, ela fala para si, não pelo fato de estar em dificuldade, mas para compreender o mecanismo presente na relação fonema / grafema: "Ela repete várias vezes o som, há um esforço intelectual para descobrir qual letra faz aquele som" (CAVATON, 2010, p. 161). Foram observadas ainda funções da fala egocêntrica na construção de conhecimento na intersubjetividade, tais como: a de geradora da fala comunicativa, em que um enunciado sobre si serve de interlocução para que o coletivo realize determinada atividade, por exemplo, "o caso de Clara, quando de seu anúncio de desenhar o castelo [...] levou outras meninas a também desenharem [...] a partir de então, todos passaram a falar o que iam fazer [...]"; a de provocadora de questões no ouvinte ao solicitar esclarecimentos ao falante, como quando “[...] Felipe narrando sua história [...] o colega quis ver e saber do que tratava [...]. O Felipe elaborou sua explicação apresentando suas estratégias de imaginar a história."; a de eliciadora de outras falas egocêntricas em diversos falantes: "É o caso de Renato e seus colegas, em que um dos meninos começou a nomear seus desenhos [...] e gerou a nomeação de outros elementos pelos demais meninos [...]; e a de geradora de avaliação, quando algum ouvinte reconhece um fato por ele considerado como errôneo e busca corrigi-lo (CAVATON, 2010, p. 96).

\subsection{Pesquisas sobre a fala egocêntrica: segunda tendência}

Em prosseguimento, são considerados aqueles estudos que se enquadram na segunda tendência, uma vez que proclamam as concepções de Vigotski a respeito da fala egocêntrica, no entanto, procuram ampliar o entendimento desse fenômeno com base em outros teóricos. Destaca-se que, em tais estudos, os sujeitos investigados são adultos aprendizes de língua estrangeira.

A pesquisa de Ferreira (2000) representa um importante esforço nesse sentido. Com o intuito de estudar a fala privada em sua relação com a habilidade oral, de forma a indicar alternativas para melhores 
práticas didático-pedagógicas em língua estrangeira (LE), propõe sua abordagem sob uma perspectiva dialógica. Segundo a autora, as definições de fala privada, decorrentes das interpretações da própria concepção de linguagem em Vigotski, em especial pelos estudiosos da língua estrangeira, limitam-se à consideração de que é um fenômeno linguístico, no qual as elocuções do falante são dirigidas a si próprio, com as funções de autorregulação, de natureza cognitiva e de alívio emocional. A discordância está no fato de não ser levada em conta a função comunicativa da fala privada, em uma relação dialética com a cognitiva. De acordo com Ferreira (2000), tomando-se o estabelecido, na perspectiva de Vigotski, de que as funções mentais superiores têm seu desenvolvimento, em primeira instância, no plano interpsicológico, para posteriormente se manifestarem no intrapsicológico, em que a consciência é, então, socialmente dada, e que a lógica do discurso interior é a da sociedade, da interação verbal e do psiquismo, pode-se deduzir que a fala privada, pertencente ao psiquismo individual, não é totalmente privada, porque sua origem é social.

Esse aspecto salientado por Ferreira (2000) é igualmente passível de ser defendido com base em Bakhtin, já que, sendo a palavra um signo ideológico, gerado em sociedade, o discurso interior também será dirigido pela ideologia, não sendo possível, por conseguinte, a distinção nítida entre linguagem interna e externa. E mais árdua ainda seria a diferenciação entre a linguagem externa e a fala egocêntrica, compreendendo-se que esta seja de caráter intermediário. Assim, parece inútil insistir na rigorosa delimitação entre os enunciados sociais e os privados.

A pesquisa de campo de Ferreira (2000) foi efetuada em um centro de línguas de uma universidade federal, em duas turmas de nível iniciante - formadas, na maioria, por estudantes universitários de diferentes cursos-, em que foram observadas aulas de inglês, em específico, momentos de prática oral oferecidos pelo professor aos alunos, em pares.

$\mathrm{Na}$ análise dos resultados, a autora buscou evidenciar que a fala social e privada convivem dialogicamente, não sendo passíveis, na produção linguística, de separações rígidas. Embora haja o convívio da fala social com a fala egocêntrica, esta tem sua existência, a qual pôde 
ser identificada por marcas linguísticas indicativas do processo de reflexão sobre a língua, da atividade epi / metalinguística, as quais se referiram ao processo de elaboração e reelaboração, que ocorreu por meio de repetições, uso da linguagem materna, alongamento de sons e tentativas de elaboração, acompanhadas de apelo ao interlocutor, com interjeições e traduções de termos. Tal processo interno expressa o alcance de compreensão e o embate do aluno com a língua estrangeira, de maneira reflexiva e elaborativa (ações epi e metalinguística), o que perpassa o processo de composição do enunciado, que é externo (ação linguística). A autora aponta ainda para a importância de esse trabalho com a língua(gem) ser respeitado e considerado pelo professor.

A pesquisa de Pinho (2009), também retratada em Pinho e Lima (2010), teve o propósito de investigar o papel da fala privada na aprendizagem de inglês, como língua estrangeira, por meio da análise de sua utilização por adultos envolvidos em tarefas colaborativas. Pinho (2009) destaca que, apesar de os estudos vigotskianos indicarem que a fala privada pode ser diferenciada da fala social, com base nos critérios de predicação, condensação e subvocalização, outras pesquisas têm demonstrado que essa diferenciação não é tão nítida, visto que a fala social pode ter função regulatória, e a privada, a faculdade de compartilhar de propriedades estruturais com a comunicação social.

A investigação empírica de Pinho (2009) contou com a participação de catorze alunos de duas turmas de um curso de inglês de uma universidade federal. Os alunos eram de nível iniciante e préintermediário, com idades entre 32 e 54 anos. O estudo contemplou a aplicação de uma tarefa desafiadora colaborativa, em duplas, e os dados foram gravados em áudio e vídeo.

Os resultados revelaram que a natureza dos diálogos, presentes durante a realização da tarefa, influenciou a produção da fala privada vinculada à social. $\mathrm{O}$ uso da fala privada compareceu na busca de compreensão da tarefa, na manutenção do foco, na organização do raciocínio, assim como estratégia autorreguladora recíproca, nesse caso, na forma de diálogo ou por meio de metacomentários, para alívio emocional. A ocorrência da fala privada, na presença de outrem, favoreceu não somente a construção do conhecimento individual, como também do coletivo. Os participantes "pensavam em voz alta", com 
propósito tanto cognitivo como social, havendo o intercâmbio entre as atividades intrapsicológicas e interpsicológicas (PINHO, 2009, p. 72).

A pesquisa de Quast (2009) parte das críticas de Vigotski quanto às acepções sobre linguagem interior vigentes em sua época e, além de enfocar alguns aspectos salientados nos estudos em torno da fala privada / interna, as funções e papéis para elas apontadas e a questão da dicotomia interno / externo, relaciona-se ao trabalho de Ferreira (2000), que faz um esforço para vencer a dicotomia social / privado. Além do mais, com base nos trabalhos do Círculo de Bakhtin, busca redimensionar a compreensão da fala privada. Assim, parte da hipótese de que a investigação da fala privada (responsável pela compreensão consciente, pelo planejamento, monitoração, autorregulação, autorreflexão, reelaboração, (re)estruturação do pensamento) poderia permitir reflexões sobre a relação discurso / cognição e a apropriação da língua estrangeira.

Essa pesquisa, a qual se insere no campo de ensino-aprendizagem de línguas estrangeiras (LEs), foi conduzida pela professorapesquisadora em uma Instituição Federal de Ensino Superior do Estado de São Paulo. Os participantes foram três alunos, com idade entre 18 e 22 anos, que não haviam cursado inglês em institutos de línguas, previamente. A metodologia de pesquisa empregada fora o paradigma indiciário ou modelo epistemológico baseado na semiótica, além da análise microgenética. Entre os instrumentos usados para coleta dos dados, encontram-se as entrevistas informais, a gravação em vídeo das aulas (e posterior transcrição), além do diário da professora e dos relatos verbais espontâneos dos alunos.

Quast (2009) aborda os problemas metodológicos que a maioria dos pesquisadores procede, ao "recortar" a fala privada, entre os quais está a diferenciação entre fala privada e fala social, que, segundo a autora, é algo extremamente complexo, pois a fala privada compartilha propriedades da fala social, enquanto a fala social também atua como autorreguladora.

No plano epistemológico, ao passo que as pesquisas revisadas partem de uma abordagem monológica, Quast (2009) se embasa em uma perspectiva dialógica, bakhtiniana, de linguagem. A fala privada é tomada, portanto, como indício da atividade que ocorre no âmbito do 
discurso interior, podendo exprimir parte do diálogo que ali se desenrola. A partir disso, com base no signo ideológico, no dialogismo, devido a cada enunciado já ser uma tomada de posição avaliativo-valorativa, conter ao menos um ponto de vista, estar sempre orientado ao outro, a autora arriscou afirmar que a fala privada é argumentativa. Quast (2009) enfatiza, igualmente, a atividade epilinguística, constituída das ações sobre a linguagem, ou melhor, da reflexão que envolve os recursos expressivos enquanto objeto. Na idade adulta não se trataria mais de "fala egocêntrica", mas de atividade epilinguística, a qual integra o processo verbal.

Os resultados de sua pesquisa enfatizam a plurifuncionalidade da fala privada e que ela pode estar misturada à fala dirigida ao outro, presente na interação. Indicam, em acréscimo, sua natureza dialógica e argumentativa. Verifica-se um denso diálogo entre palavras, enunciados, contextos, confrontos de vozes e posições, desvelando a intensa movimentação e interlocução que acontecem nessa fala, a qual pode ser, em várias circunstâncias, tratada com indiferença, ou ainda, calada. Chama-se a atenção ao fato de que a fala em questão pode dar sinais do trabalho realizado no processo de constituição de conhecimento, revelando outros elementos da dinâmica discursiva de sala de aula, até então inaudíveis.

3.4 Pesquisas sobre a fala egocêntrica: terceira tendência

Será abordado, enfim, o estudo de Lier-De Vitto (1994), que se enquadra na terceira tendência, uma vez que, apesar de sinalizar para os trabalhos de Piaget e Vigotski, diferentemente dos demais, oferece outra abordagem sobre a fala egocêntrica, a qual não se fundamenta à luz nem da perspectiva histórico-cultural, nem da Epistemologia e Psicologia Genéticas. Além disso, o foco, nessa tendência, está na criança em sua tenra infância, uma vez que se volta a estudos sobre os monólogos no berço, em especial nas situações em que a criança está sozinha.

Em sua pesquisa, Lier-De Vitto (1994) objetiva localizar o porquê da presença sintomática dos monólogos (fala descontínua e irregular) e oferecer uma interpretação alternativa para eles. A autora mostra-se afiliada ao interacionismo, por meio do qual tem sua definição 
maior na noção de especularidade e na proposição de que, ao se ter que se colocar diante da linguagem a conhecer, a interação com o outro se torna uma condição necessária. Nessa proposta, o outro é apresentado como lugar de funcionamento, isto é, enquanto discurso ou instância de funcionamento da língua constituída; e o sujeito é "lugar" em que se tecem as tramas das relações e dos sentidos: ele não está diante da linguagem, mas a linguagem acontece nele, o atravessa, desliza e / ou se articula.

A autora efetua uma revisão bibliográfica acerca de produções sobre os monólogos das crianças, a iniciar por Piaget e Vigotski, avançando, posteriormente, para a área da Aquisição da Linguagem, especialmente pela obra de Ruth Weir (1962). Ao argumentar sobre o fato de a linguagem ser condição necessária, mas insuficiente, na teoria de Piaget, Lier-De Vitto (1994) ressalta que Piaget (1945 [1975]), na obra $A$ formação do símbolo na criança, não abandona os pontos de vista assumidos em $A$ linguagem e o pensamento (Piaget, 1923 [1986]), pelo contrário, que o paralelismo entre os desenvolvimentos cognitivo e social nesta declinado ganha consistência naquela, ao ser subordinado ao funcionamento de um regulador central. No esforço dessa explicação, Lier-De Vitto (1994) se opõe a Piaget, por retirar da linguagem o poder de significar. A linguagem se constitui como condição necessária, mas não suficiente à constituição das operações, sendo necessária a sua "formulação" ou objetivação, mas nunca a sua construção. Para a autora, na descrição de Piaget de que o monólogo seria "[...] a fala por meio de frases curtas, entrecortadas de silêncios prolongados ou de palavras de outras crianças" (LIER-DE VITTO, 1994, p. 36), essas palavras dos outros são presenças no falar da criança, como contraface de seu silêncio, espelhando, inclusive, sua sociabilidade - e não o contrário-, de modo que critica o estudioso, por não enxergar o avanço dessa linguagem e têla concebido como "sinal negativo", no que concerne à socialização.

Embora haja uma divergência radical entre as trajetórias do desenvolvimento ontogenético concebidas por Piaget e Vigotski, segundo a autora, este mantém a fala egocêntrica, a exemplo de Piaget, no livro de 1923 (PIAGET, 1923 [1986]), como lugar empírico de expressão de um plano que não se dá a ver, reinterpretando-a no sentido de lhe atribuir um estatuto capaz de torná-la mais ajustada ao modelo de 
desenvolvimento que propõe. Esse é o motivo de a ideia de internalização se impor, sendo a fala egocêntrica chamada a explicitar o início e o desenvolvimento desse processo, conferindo-se a ela o estatuto de elo genético (período de transição).

A autora aponta ainda que, para Vigotski, é na fala egocêntrica que se realizaria o cruzamento entre as linhas genéticas, até então independentes, para inaugurar as "formas tipicamente humanas" de comportamento; contudo, ele não esclarece o que leva à convergência dessas linhas, de maneira que ela o critica, porque, acima de tudo, isso não exclui o impasse decorrente da permanência da dicotomia interno / externo (a separação dos domínios da função externa / interpessoal e a função interna / intrapessoal da linguagem). Conquanto, incontestavelmente, os passos de Vigotski resultassem na novidade da introdução da linguagem como elemento revolucionário na Psicologia do Desenvolvimento, a fim de realizar o deslocamento teórico que almejou (o de colocar a linguagem como protagonista), Vigotski teria que remover, ou melhor, romper, o obstáculo inicial, ou seja, sua aceitação da separação interno / externo. Assim, teria de haver uma ruptura na explicitação de que a linguagem é um mero instrumento inter ou intrapsicológico de regulação, ou de controle de comportamento, passando a desempenhar o papel de "estruturante", com um modo de funcionamento como produtora de sentidos.

Segundo Lier-De Vitto (1994), Ruth Weir (1962) aproxima-se de Vigotski, ao assumir que a noção de internalização implica uma subjetividade que se desenvolve e se consolida em uma esfera privada, em um retiro interno / individual. Nesse sentido, os monólogos, na opinião de Weir (1962), refletirão esse momento crucial da unificação do sujeito, no qual ele passa a objeto de si mesmo; no entanto, a "natureza dialógica do discurso interior" fica diluída no interior de um trabalho cujo objetivo primeiro é oferecer, com base nos monólogos no berço, argumentos favoráveis à ideia de que as "produções solitárias" da criança exibem sua independência em relação ao outro, independência que é correlativa ao controle gradual que passa a ter dos padrões da língua.

Entretanto, a importância de Ruth Weir é ressaltada, pois, conforme a autora, é ela que localiza um problema que se pode dizer propriamente teórico. Embora tenha mantido a hierarquia entre a 
aquisição do sistema subjacente e o discurso, Weir (1962) se inquieta e procura atribuir dignidade ao "discurso cotidiano". É no caminho aberto por Weir (1962) que Lier-De Vitto (1994), com sua posição interacionista, vai considerar que os monólogos deixam ver, sobretudo, sua determinação dialógica e discursiva. Sustentar que nos monólogos a criança "fala de si" e "para si" significa negar que lá estejam o outro e os outros. Significa, igualmente, atrelar interação à ideia simplista de alternância ou reversibilidade de papéis entre indivíduos / sujeitos, entre "seres-em-si-mesmos". Os "erros categoriais", arranjos textuais desajeitados, inconclusos, e a "falta de clareza" dessas produções são momentos em que a criança decide explorar a linguagem: quando predomina a função poética, ela "explora intencionalmente" os sons da linguagem; quando está em questão a função metalinguística, ela interrompe o discurso para "testar" itens em uma posição particular num "padrão estrutural"; quando prevalece a função fática, os ruídos e os vocativos denunciam a "determinação" da criança em "manter o canal aberto"; ou seja, dependendo da intenção de momento da criança, a fluência discursiva será afetada.

Para a autora, portanto, vozes diversas circulam na criança, nos diálogos e nos monólogos. Nos diálogos, a criança tem a palavra do outro, daquele que, por ser da ordem da linguagem, tira da deriva os fragmentos múltiplos que circulam pela voz da criança, ao submetê-los à cadeia significante num domínio de sentido particular. Nos monólogos, os enunciados articulam-se dialogicamente, mas nem sempre têm direção. Será frente aos monólogos que o sujeito irá nascer no campo da linguagem, onde se encontrará no outro e com ele mesmo. E o que conta nesse outro é exatamente o que ele fala. Por isso, a questão relativa à condição de produção dos monólogos deve ser colocada indagando-se sobre o efeito que tem, sobre a criança, o silêncio do outro. Lier-De Vitto (1994) conclui, então, que é nesse silêncio que o sujeito é situado no interior de uma articulação significante a qual o aprisiona em redes históricas que se entrecruzam, resultado este decorrente da condição de produção de "não ser escutado".

\section{Discussões}


Inicialmente, chama a atenção a escassez de pesquisas sobre o tema tratado, considerando o período de busca, ou seja, em três décadas, conforme informações disponíveis no Banco de Teses da CAPES, somente oito investigações se voltaram para a análise da fala egocêntrica, três na década de 1990, e cinco no período de 2000 a 2010. Destaca-se também o fato de, entre as produções encontradas, nenhuma abordar a fala egocêntrica à luz da Epistemologia e Psicologia Genéticas; na maioria dos casos em que há referência a essa perspectiva, ressaltam-se as críticas de Vigotski às interpretações de Piaget, a despeito de se reconhecer sua importância e pioneirismo, nesse âmbito. Há ainda aquelas estudiosas (FERREIRA, 2000; PINHO, 2009) para as quais, mais do que discordâncias entre as concepções de Piaget e Vigotski sobre a fala egocêntrica, existiriam diferentes elementos de análise, sob a argumentação de que a distância entre ambos se daria mais pelo interesse de investigação do que pelas formulações em si. Piaget teria se voltado mais a aspectos relativos à (não) sociabilidade, enquanto Vigotski teria privilegiado à implicação dessa linguagem no desenvolvimento cognitivo. Lier-De Vitto (1994) levanta em sua tese, conforme suas próprias palavras, "pontos de contato no fundamental" entre Piaget e Vigotski, sendo que o principal seria a circunstância de ambos aceitarem a dicotomia interno / externo, ou seja, um domínio subjetivo / inacessível / interno e outro objetivo / social / externo.

Nesse mesmo sentido, quanto à diferenciação que pode ser evidenciada no que tange à idade dos participantes conforme as diferentes tendências, na primeira, que tem como referencial os pressupostos de Vigotski, em que os estudos são feitos com crianças em idade pré-escolar, a linguagem egocêntrica é retratada, sobretudo, no percurso genético da constituição das funções psicológicas superiores, como um "elo" de transição entre o discurso social e o interno, e em sua função fundamental no desenvolvimento do pensamento infantil. Ela se manifesta no momento da passagem dos processos interpsicológicos para os intrapsicológicos, por isso mantém a forma da fala socializada e a função da linguagem interior.

Quast (2009, p. 63) esclarece que a fala egocêntrica na criança possibilita visualizar como duas linhas genéticas, que tinham seu 
desenvolvimento paralelamente (o pensamento pré-verbal e a linguagem pré-intelectual), encontram-se e originam uma "forma especificamente humana de funcionamento verbal", o pensamento verbal, que passa a ser mediado simbolicamente pela linguagem, transformando a organização da consciência. Em sua interpretação, a autora aponta para a discussão de Vigotski com relação à fala egocêntrica como vinculada às novas funções que a linguagem assume na criança, o que the permite formas mediadas de ação. Porém, segundo a autora, não obstante Vigotski anunciar o funcionamento dialógico da fala egocêntrica e da linguagem interior, ele não vai adiante nesse sentido, oferecendo pouca contribuição ao entendimento da fala egocêntrica no adulto.

Assim, podemos entender porque em estudos sobre esse tipo de fala em adultos, como é o caso daqueles denominados neste texto como da segunda tendência, os pesquisadores buscam se fundamentar também em outros teóricos, em especial em Bakhtin, de modo a considerarem a função comunicativa da fala privada, e sua convivência dialógica com a fala social.

De acordo com Ferreira (2000), as limitações de estudos de autores circunscritos a Vigotski e que, predominantemente, realizam suas pesquisas em crianças é a de que a fala privada seria considerada como, principalmente, voltada para si mesmo com as funções de autorregulação, de natureza cognitiva e de alívio emocional, não se contemplando o papel comunicativo da fala privada, em uma relação dialética com a dimensão cognitiva. E, segundo Pinho (2009), deve-se haver uma compreensão diferente da fala egocêntrica / privada com relação à sua manifestação na criança e no adulto, uma vez que enquanto na primeira sua constituição ainda está atrelada ao desenvolvimento do pensamento verbal, no adulto, comparece mais como um meio de autorregulação do próprio comportamento. No entanto, a fala privada também pode assumir outras funções, tal como apontado por Quast (2009), em que, ao se considerar a indistinção entre interno e externo e considerar a linguagem como atividade significante, ela pode se revelar em sua complexidade, e como um indício da atividade que ocorre no âmbito do discurso interior, porém pressupondo um interlocutor e exprimindo parte do diálogo que ali se desenrola, e não unicamente como internalização da linguagem ou em sua função de autorregulação. 
Apesar dessas diferenças, podem ser reconhecidos os alcances dos estudos que se inserem nas três tendências. Naqueles da primeira tendência, que desenvolveram suas pesquisas com crianças em idade préescolar, são realçadas as seguintes contribuições: indicam a relevância da fala egocêntrica para a compreensão de aspectos essenciais da teoria de Vigotski, como da passagem do interpsíquico para o intrapsíquico (AGUIAR, 1998); confirmam, empiricamente, formulações de Vigotski a respeito, tal qual o estudo de Andrada (2006), que verificou nas crianças participantes de sua pesquisa, primeiramente, o caráter descritivo da fala egocêntrica, e, posteriormente, sua função planejadora; e não obstante irem ao encontro dos postulados de Vigotski, enfatizam aspectos que podem ser considerados, até mesmo, originais, como o trabalho de Cavaton (2010), que reitera o papel de organização e regulação da fala egocêntrica, mas também ressalta a possibilidade de esse tipo de linguagem ser direcionado ao outro social, o que dá destaque à sua função de eliciadora da fala comunicativa e da construção do conhecimento, na relação interpsicológica.

No que tange às implicações educacionais apontadas por esses estudos, Azulay (1995), Andrada (2006) e Cavaton (2010) indicam a importância de se reconhecer as intenções e necessidades de expressão da criança, assim como seu papel ativo na construção do conhecimento, em que algumas estratégias são colocadas em ação - entre as quais a fala egocêntrica. Além disso, ao enfocar a função de autorregulação da fala egocêntrica, na perspectiva de Vigotski, Cavaton (2010) arrola várias pesquisas recentes que atestam a validade dos postulados de Vigotski sobre esse aspecto no desenvolvimento de tarefas escolares, podendo, até mesmo, atuar como Zona de Desenvolvimento Proximal.

Verifica-se, assim, que esses trabalhos propiciam o entendimento da fala egocêntrica e, essencialmente, confirmam as formulações de Vigotski e a relevância de se considerar esse fenômeno no contexto educativo, para que tenha sua livre manifestação e que, ao contrário de ser repreendido, seja utilizado como um instrumento promovedor do aprendizado e, consequentemente, do desenvolvimento cognitivo. Notase, igualmente, que Azulay (1995), Andrada (2006) e Cavaton (2010) citam Bakhtin, em seus estudos - teórico bastante lembrado por aqueles autores que procuram trazer novas compreensões para o fenômeno em 
pauta - no entanto, esse mesmo autor não é empregado nesses trabalhos, com o propósito de entender e / ou explicar a fala egocêntrica.

Quanto aos trabalhos qualificados como da segunda tendência, de início, esses merecem reparo no emprego do termo fala privada em vez de fala egocêntrica. Em relação a esse fato, as autoras exploram justificativas com base em Flavell (1966), que foi quem o cunhou, porém, elas se valem de diferentes argumentos. Ferreira (2000) salienta os problemas da terminologia fala privada, por remeter literalmente à fala para si próprio, acessível apenas a si, que não é pública, apenas privada. E, a despeito de utilizá-lo, admite sua preferência por fala egocêntrica - termo adotado por Piaget-, por concordar com o sentido presente nessa perspectiva, que considera, mesmo que seja de maneira frágil, o aspecto dialógico, já que esse teórico considerou o monólogo coletivo. Pinho (2009) e Pinho e Lima (2010), por sua vez, destacam que a adoção do termo fala privada se deu por trazer a marca de autorregulação da fala, de modo que representa melhor o significado atribuído na perspectiva de Vigotski, assim como anuncia o retorno da fala egocêntrica no adulto, no esforço de autocontrolar seu comportamento.

Quast (2009) emprega igualmente o termo fala privada, para fazer referência à fala egocêntrica, conforme discutida por Vigotski. Elege esse termo, observando a recomendação de que não possui a acepção de inabilidade de adotar a perspectiva do outro, relacionada à interpretação piagetiana. E, ainda que entenda que ambas as terminologias soem inadequadas, decide pela manutenção de fala privada, porque é usada no campo de aquisição de segunda língua / língua estrangeira (SLA), à luz da perspectiva Histórico-Cultural.

Conquanto o texto de Smolka (1993) não integre o conjunto de trabalhos atinentes à pesquisa bibliográfica aqui apresentada, é proveitoso fazer referência a ele, uma vez que evidencia como o estudo desse aspecto do desenvolvimento humano traz ambiguidades, dissensos e problemas de interpretação. Conforme Smolka (1993), uma das dificuldades em nomear o fenômeno da fala egocêntrica está em sua associação com o que Piaget chamou de pensamento egocêntrico, e à concepção, nesse contexto, de que a fala egocêntrica, como não socializada e não comunicativa, parece prescindir, totalmente, da 
presença física ou imagem internalizada do outro, em que a orientação da vocalização como "fala para si" deixa de levar em conta a possibilidade de verbalização "para o outro". Não concordando com esse sentido proveniente da perspectiva piagetiana, Smolka (1993) analisa a possibilidade do uso de private speech, proposto por Flavell, o qual ela também considera como inadequado na versão em português ("fala privada"), já que Smolka (1993) propõe uma leitura mais dialógica. Em face da impropriedade dos termos, sugere a continuidade do uso de fala egocêntrica. Nota-se, assim, que as interpretações de Smolka (1993) são confirmadas por Quast (2009), todavia, por outro lado, são discrepantes com respeito às de Ferreira (2000).

É grande a pertinência em recorrer a Smolka (1993), nesse contexto, pois é justamente a compreensão à qual ela se refere - de uma leitura mais dialógica - que representa o elo entre os estudos da segunda tendência.

Não obstante Smolka (1993) se posicionar de maneira a atribuir à hipótese de Vigotski maior razoabilidade quando comparada à de Piaget, para explicar o fenômeno da fala egocêntrica, ela afirma que aspectos das formulações de Vigotski apresentam algumas dificuldades que merecem mais investigações. A discussão fundamental refere-se à concepção de Vigotski da fala egocêntrica como um "estágio" de "transição", de "elo intermediário" no processo de internalização, de "precedência" em relação à fala interna, o que conduz a uma linearidade que precisa ser reconsiderada, entre "[...] fala social (oral) / fala egocêntrica / fala interna / (e posteriormente) a escrita [...]" (SMOLKA, 1993, p. 39).

De acordo com Smolka (1993), no estudo da oralidade, da escrita e da fala interna, Vigotski afirma que, enquanto a fala externa, a qual possui predominantemente uma estrutura estendida, é a fala para o outro, a fala interna é a fala para si, com estrutura abreviada e predicativa. A fala egocêntrica, por sua vez, passa por diferentes estados, os quais antecedem o desenvolvimento da fala interna: da extensão à abreviação; é a mediação no movimento de internalização da fala externa, de forma a marcar a transposição fala-para-o-outro/fala-para-si e o surgimento das funções de planejamento e autorregulação. Para Vigotski, a forma oral da 
linguagem é comumente dialógica, enquanto a escrita e a fala interna são formas monológicas.

O critério para a diferenciação entre as formas dialógicas e monológicas, usado por Vigotski, é a presença ou ausência de interlocutores nas situações concretas dos intercâmbios verbais. Conforme a autora, apesar de Vigotski ter considerado a natureza social e dialógica da linguagem, ele não elaborou de maneira explícita a dialogia internalizada, tanto no que diz respeito à atividade mental individual como sobre a escrita. E, segundo ela, é Bakhtin que possibilitará ampliar o conceito de diálogo, ao propor que as palavras alheias se transformarão em palavras próprias, as quais, ao serem incorporadas, se tornarão progressivamente anônimas, em um processo de monologização da consciência.

Esse processo, descrito por Bakhtin, de apreensão e transformação da fala do outro na constituição de significados e sentidos, vai ao encontro da noção de internalização proposta por Vigotski. O monólogo será, por conseguinte, a reprodução de um diálogo que o excede, pressupondo que a linguagem sempre consistirá em alguém falando para outro, mesmo que este seja um interlocutor ou um destinatário interior. O que caracteriza e define a dialogia, em Bakhtin, é justamente aquilo que o diferencia de Vigotski, a "[...] necessária orientação para o outro", podendo-se prescindir da "presença do outro" (SMOLKA, 1993, p. 44).

Voltando-se aos estudos da segunda tendência, é possível confirmar, seja naqueles trabalhos fundamentados em Bakhtin, como os de Ferreira (2000) e Quast (2009), seja nos que não mencionam esse teórico, como o de Pinho (2009), ou até mesmo o de Lier-De Vitto (1994) - da terceira tendência -, a centralidade da dialogia na compreensão da fala egocêntrica, em que é defendida a recusa de posições dicotômicas e / ou lineares e reconhecida a dificuldade de nítida diferenciação entre esse tipo de fala e a social, já que a primeira tem um caráter intermediário, sendo inútil instar na rija delimitação entre os discursos sociais e os privados. Em acréscimo, é necessário admitir as inter-relações entre as funções comunicativas e reguladoras da linguagem (FERREIRA, 2000); certo tipo de fala é passível de conter propriedades do outro, visto que a fala social pode apresentar funções de 
autorregulação, ao passo que a privada é suscetível de emergir em um espaço capaz de privilegiar a linguagem, em sua função comunicativa (PINHO, 2009).

Munidas desses pressupostos, essas estudiosas descortinam as marcas da dialogia, na fala egocêntrica, por meio de seus dados de campo, resultantes de pesquisas com adultos, entrelaçadas com as implicações educacionais que sugerem. Em vários casos, são justamente essas implicações que dão propulsão às investigações, uma vez que se têm como prioridade o uso cognitivo da fala egocêntrica e sua ligação com elementos comunicativos. Nesse sentido, buscam verificar como essa linguagem pode favorecer processos educativos, principalmente em adultos aprendizes da língua estrangeira. $\mathrm{E}$ os resultados confirmam essa direção. Tanto os dados de Ferreira (2000) como os de Quast (2009), por exemplo, evidenciam que, na aprendizagem da língua estrangeira, em atividades com pares, a fala privada e a social convivem dialogicamente, mesmo sendo possível delimitar a existência e função da privada, mediante diversas estratégias cognitivas - de elaboração, reelaboração, reflexão, interjeição, entre outras-, que favorecem o empenho e aprendizado dos alunos. Cavaton (2010), Pinho (2009) e Pinho e Lima (2010) enfatizam a relação da fala egocêntrica com a Zona de Desenvolvimento Proximal, seja por atuar dentro desse espaço, já que tende a comparecer quando as atividades são desafiadoras, seja por expandir capacidades cognitivas, tendo-a como recurso regulador.

Observa-se que, malgrado Ferreira (2000), Pinho (2009) e Pinho e Lima (2010) admitam, em relação à fala egocêntrica, uma dialogia constitutiva, dando maior ênfase que a atribuída por Vigotski à sua função comunicativa, além de a cognitiva e de alívio emocional, os dados de suas pesquisas de campo se restringem aos contextos interativos, ou seja, à presença (física) do interlocutor, diferentemente de Quast (2009), por exemplo, que, tal como Smolka (1993), dá saliência à dialogia internalizada. Assim, Quast (2009) apresenta possibilidades de análise da linguagem egocêntrica que extrapolam o observável, permitindo vislumbrar o diálogo, no até então considerado monológico, pressupondo-se os diferentes contextos e interlocutores que, embora não estejam presentes materialmente, têm sua existência e participação 
psicológica. Atribui-se à fala egocêntrica, pois, a representação externa de diálogos internos, que podem e devem ser reconhecidos.

\section{Considerações finais}

Procurou-se, com este estudo, contribuir para a divulgação de pesquisas nacionais sobre a fala egocêntrica, produzidas em diferentes Programas de Pós-Graduação, assim como ampliar sua compreensão, por meio da apresentação de dados científicos, favorecendo sua acessibilidade a pesquisadores e educadores.

Salienta-se que, apesar de a questão da fala egocêntrica ter sido tematizada e discutida por Piaget e Vigotski, é viável atentar para a escassez de trabalhos nacionais mais atuais que abordem esse fenômeno como objeto de estudo, o que sugere o pouco interesse demonstrado por esse aspecto. Adverte-se ainda que as reflexões de Piaget a esse respeito constituem um domínio que tem sido "negligenciado" nas pesquisas - o que, de certa maneira, acaba reforçando e validando as críticas sobre a irrelevância da questão linguística, em sua perspectiva-, e tais reflexões implicam uma compreensão que merece ser discutida nos dias de hoje.

Não obstante terem sido encontrados poucos trabalhos, destaca-se sua relevância e peso, sobretudo daqueles que não se limitam às formulações iniciais de Vigotski e buscam redimensionar a compreensão da fala egocêntrica, com o foco embasado, especialmente, nos trabalhos do Círculo de Bakhtin. Com efeito, a maioria destes tem concebido a fala dirigida ao próprio sujeito como dialógica, procurando suprimir a dicotomia interno / externo, social / privado.

Observou-se ainda que os estudos se diferenciam conforme as características dos sujeitos pesquisados, mormente àquelas relativas à idade e aos contextos em que os esses sujeitos se situam. Nesse sentido, no referente às implicações educacionais, na primeira tendência, dá-se relevância à importância de se considerar as necessidades e intenções de expressão da criança, e o alcance da fala egocêntrica como atividade de planejamento, organização e autorregulação em tarefas cognitivas e escolares, assim como para a aprendizagem e desenvolvimento da criança. 
$\mathrm{Na}$ segunda tendência, as implicações voltam-se, de modo geral, e principalmente, à contribuição do papel da fala privada na compreensão do processo de ensino-aprendizagem inerente à apropriação da língua estrangeira em adultos aprendizes, sendo, então, investigada em sua relação com a habilidade oral. É enfatizada a relevância de se estudar seu uso cognitivo e regulador (mas não ficando restrito a ele), assim como para a compreensão de como os alunos buscam a superação de suas dificuldades na comunicação em língua estrangeira.

$\mathrm{Na}$ terceira tendência, as implicações teriam seu alcance na determinação dialógica e discursiva da linguagem na constituição do sujeito na tenra infância. Por fim, independentemente da tendência a partir da qual a fala egocêntrica / privada seja abordada, esta deve ser reconhecida, respeitada e estudada, em vários contextos e em manifestação pelos diferentes sujeitos. E, sobretudo, deve-se ter com relação a tal fala uma postura de escuta ativa e atenta, uma vez que sua expressão propicia o acesso a processos de elaboração, reflexão, planejamento, organização, autorregulação, e de construção do conhecimento pelo próprio sujeito e de modo intersubjetivo, na interação com o outro. Por conseguinte, a fala egocêntrica pode revelar ao educador não somente as dificuldades de seus alunos mas também aquilo que o sujeito coloca em pauta para a compreensão dos mecanismos da própria ação e o que por ele está em apropriação e / ou já foi apropriado. Estudos evidenciam ainda a dimensão dialógica dos enunciados desse tipo de fala, ou seja, sua função comunicativa em uma relação dialética com a cognitiva.

\section{Referências}

AGUIAR, Maria Aparecida Lapa. A relevância da linguagem para o desenvolvimento humano: contribuições da perspectiva vygotskiana para a educação. 1998. 140p. Dissertação (Mestrado em Educação) Universidade Federal de Santa Catarina, Florianópolis, SC, 1998.

ANDRADA, Lorena Pimenta de. Interação e construção de conhecimento em situação de roda na Educação Infantil. 2006. $176 \mathrm{f}$. 
Dissertação (Mestrado em Psicologia) - Universidade de Brasília, Brasília, DF, 2006.

AZULAY, Kelman Celeste. Sons e gestos do pensamento: um estudo sobre a linguagem egocêntrica na criança surda. 1995. 106f. Dissertação (Mestrado em Educação) - Universidade do Estado do Rio de Janeiro, Rio de Janeiro, RJ, 1995.

BAKHTIN, Mikhail. Problemas da poética de Dostoiévski. Rio de Janeiro: Forense Universitária, 1981. (Original publicado em 1929).

BAKHTIN, Mikhail (VOLOCHÍNOV, V.N.). Marxismo e filosofia da linguagem. Problemas fundamentais do método sociológico na ciência da linguagem. São Paulo: Hucitec, 1986. (Original publicado em 1929).

BAKHTIN, Mikhail. Estética da criação verbal. São Paulo: Martins Fontes, 1992. (Original publicado em 1979).

BERK, Laura. Crianças que falam sozinhas. Revista Mente e Cérebro, Ano XIV, n. XIV, jan. 2007.

CAVATON, Maria Fernanda Farah. A mediação da fala, do desenho e da escrita na construção de conhecimento da criança de seis anos. 2010. 174f. Tese (Doutorado em Processos de Desenvolvimento Humano e Saúde) - Universidade de Brasília, Brasília, DF, 2010.

DIAZ, Rafael M. Methodological concerns in the study of private speech. In: DIAZ, R. M.; BERK, L. E. (Org.). Private speech: from social interaction to self-regulation. Hillsdale, New Jersey: Lawrence Erlbaum Associates, 1992.

DIAZ, Rafael M.; BERK, Laura E. (Org.). Private speech: from social interaction to self-regulation. Hillsdale, New Jersey: Lawrence Erlbaum Associates, 1992.

FERREIRA, Marília Mendes. A fala privada (não tão) em interações de alunos realizando atividades orais em língua estrangeira. 2000. $210 \mathrm{f}$. Dissertação (Mestrado em Linguística Aplicada) - Universidade Estadual de Campinas, Campinas, SP, 2000. 
FLAVELL, John. Le Langage Privé. Bulletin de Psychologie, v.19, n.4, p. 698-701, 1966.

LIER-DE VITTO, Maria Francisca De A. Os Monólogos da criança: "Os delírios da língua". 1994. 205f. Tese (Doutorado em Ciências) Universidade Estadual de Campinas, Campinas, SP, 1994.

LIER-DE VITTO, Maria Francisca. Subjetividade e linguagem: um olhar sobre a psicologia do desenvolvimento e a aquisição da linguagem. Distúrbios da Comunicação, v. 9, n. 1, p. 22-33, dez. 1997.

MONTERO, Ignacio; De DIOS, Mária-José; HUERTAS, Juan A. El desarrollo de la motivacion en el contexto escolar: Un estudio a través del habla privada. Estudios de Psicología, v. 22, p. 305-18, 2001.

$<$ http://dx.doi.org/10.1174/021093901753581367>

MONTERO, Ignacio; De DIOS, Mária-José. Vygotsky was right. An experimental approach to the relationship between private speech and task performance. Estudios de Psicologia, v. 27, n. 2, p. 175-189, 2006. $<$ http://dx.doi.org/10.1174/021093906777571709>

PIAGET, Jean. Comentários de Piaget sobre observações críticas de Vygotsky concernentes a duas obras: A linguagem e o pensamento da criança e $\mathrm{O}$ raciocínio na criança. In: VYGOTSKY, L. S. Pensiero e Linguaggio. Firenze: Giunti, 1966. (Apêndice).

PIAGET, Jean. O raciocínio na criança. Rio de Janeiro/São Paulo: Record, 1967. (Original publicado em 1924).

PIAGET, Jean. A linguagem $\mathrm{e}$ as operações intelectuais. In: AJURIAGUERRA, J.; BRESSON, F.; FRAISSE, P.; INHELDER, B.; OLÉRON, P. (Org.). Problemas de psicolingüistica. São Paulo: Mestre Jou, 1973a. p. 63-74.

PIAGET, Jean. Estudos Sociológicos. Rio de Janeiro: Forense, $1973 \mathrm{~b}$. (Original publicado em 1965).

PIAGET, Jean. A formação do símbolo na criança: imitação, jogo e sonho, imagem e representação. 2. ed. Rio de Janeiro: Zahar; Brasília: INL, 1975. (Original publicado em 1945). 
PIAGET, Jean. A linguagem e o pensamento da criança. 7. ed. São Paulo: Martins Fontes, 1986. (Original publicado em 1923).

PIAGET, Jean. A linguagem e o pensamento da criança. 7. ed. São Paulo: Martins Fontes, 1999. (Original publicado em 1923).

PIAGET, Jean. A representação do mundo na criança. Aparecida, SP: Ideias e Letras, 2005. (Original publicado em 1947).

PINHO, Isis da Costa. A fala privada na aprendizagem de inglês como lingua estrangeira em tarefas colaborativas. 2009. 88p. Dissertação (Mestrado em Letras) - Universidade Federal do Rio Grande do Sul, Porto Alegre, RS, 2009.

PINHO, Isis da Costa; LIMA, Marília dos Santos. A fala privada no desenvolvimento de tarefas colaborativas em inglês. Calidoscópio, Unisinos, v. 8, n. 1, p. 38-38, jan./abr., 2010.

QUAST, Karin. Discurso interior e o processo de ensino-aprendizagem da língua estrangeira. 2009. 200p. Tese (Doutorado em Educação) Universidade Estadual de Campinas, Campinas, SP, 2009.

RAMIREZ, Juan D. Functional differentiation of social and private speech: A dialogic approach. In: DIAZ, R, M.; BERK, L. E. (Org.). Private speech: from social interaction to self-regulation. Hillsdale, NJ: Erlbaum, 1992. p. 199-214.

SAN MARTÍN, Concepcion. Estudio de la emergência del habla privada en una situación comunicativa infantil de juego y sus relaciones con el conflito comunicativo. Anuario de Psicología, Barcelona, v. 35, n. 1, p. 71-85, 2004.

SAN MARTÍN, Concepcion. Diversidad functional del silencio en situación comunicativa: emergencia del silencio como marcador reflexive en los mensajes infantiles. Anuario de Psicología, Barcelona, v. 39, n. 2, p. 231-248, 2008.

SMOLKA, Ana Luiza Bustamante. A dinâmica discursiva no ato de escrever: relações oralidade-escritura. In: GÓES, M. C. R; SMOLKA, A. L. B. (Org.). A linguagem e o outro no espaço escolar: Vygotsky e a construção do conhecimento. Campinas: Papirus, 1993. 
VIGOTSKI, Lev Semenovich. O instrumento e o símbolo no desenvolvimento da criança. In: VIGOTSKI, Lev Semenovich. A formação social da mente. 7. ed. São Paulo: Martins Fontes, 2007. p. 320.

VIGOTSKI, Lev Semenovich. A formação social da mente. São Paulo: Martins Fontes, 1984.

VIGOTSKI, Lev Semenovich. Pensamento e linguagem. São Paulo: Martins Fontes, 1987. (Original publicado em 1934).

VIGOTSKI, Lev Semenovich. A linguagem e o pensamento da criança na teoria de Piaget: estudo crítico. In: VIGOTSKI, L. S. A construção do pensamento e da linguagem. São Paulo: Martins Fontes, 2001. p. 19-96. (Original publicado em 1934).

WEIR, Ruth. Language in the crib. The Hage, Holanda: Mouton \& Co, 1962.

WINSLER, Adam; NAGLIERI, J. Overt and covert verbal problemsolving strategies: Developmental trends in use, awareness, and relations with task performance in children aged 5 to 17. Child Development, v. 74, p. 659-678, 2003. <http://dx.doi.org/10.1111/1467-8624.00561> 

